\section{DIGITAL COMMONS \\ @ UNIVERSITY OF SOUTH FLORIDA}

\section{ABO: Interactive Journal for Women in the Arts, 1640-1830}

Volume 2

Issue 1 Volume 2.1 (Spring 2012): Open Access

Article 7

2012

\title{
A Reflection on Teaching, Multiculturalism, and Access
}

Srividhya Swaminathan

Long Island University, Srividhya.Swaminathan@liu.edu

Follow this and additional works at: https://digitalcommons.usf.edu/abo

Part of the Dramatic Literature, Criticism and Theory Commons, Educational Methods Commons, Feminist, Gender, and Sexuality Studies Commons, and the Literature in English, British Isles Commons

\section{Recommended Citation}

Swaminathan, Srividhya (2012) "A Reflection on Teaching, Multiculturalism, and Access," ABO: Interactive Journal for Women in the Arts, 1640-1830: Vol.2: Iss.1, Article 7.

http://dx.doi.org/10.5038/2157-7129.2.1.6

Available at: https://digitalcommons.usf.edu/abo/vol2/iss1/7

This Pedagogy is brought to you for free and open access by Digital Commons @ University of South Florida. It has been accepted for inclusion in ABO: Interactive Journal for Women in the Arts, 1640-1830 by an authorized administrator of Digital Commons @ University of South Florida. For more information, please contact digitalcommons@usf.edu. 


\section{A Reflection on Teaching, Multiculturalism, and Access}

\section{Keywords}

access, Aphra Behn, cultural production, Eliza Haywood, Fantomina, multiculturalism, Oroonoko

Creative Commons License

(c) (1) $\odot$

This work is licensed under a Creative Commons Attribution-No Derivative Works 3.0 License. 
The newest trend to besiege higher education puts increased emphasis on "proving" the efficacy of the liberal arts curriculum with some quantifiable measures. This imperative introduces a new concern in pedagogy as educators seek new ways to gauge the degree of knowledge acquisition in rapidly changing classroom environments. As departments scramble to show through numbers and charts how their particular discipline engages and educates the university undergraduate, many teachers may have to re-evaluate what they perceive to be the "required" body of knowledge for their field. English departments, for example, might seek to replace the more traditional eighteenth-century studies course with a course in Anglophone Caribbean literature. Or, as in the case of service-oriented English departments, they might replace single-author or period focused courses with more surveys. Though E. D. Hirsch's idea of "cultural literacy" is highly problematic, the study of English literature rests on the development of cultural competencies that are markers of higher education. ${ }^{1}$

What impact do these developments have on the teaching of eighteenth-century literature and access to this form of cultural literacy, particularly as classrooms embrace increasing types of diversity? To address this question, I use my own experience in the classroom to understand pressures on pedagogy that operate outside of the need to teach the material. I have learned that classroom strategies cannot be considered independently of the subject-positioning of the educator herself. The field of eighteenth-century studies has a growing body of pedagogical scholarship that encourages innovative course design. ${ }^{2}$ While many of us seek to make the field more inclusive of the range of writing and writers of the time, the relevance of our field to present-day concerns can be emphasized more directly. I would argue that, as a field, eighteenthcentury studies is singularly well-placed to help students understand the complexities of cultural production, just as in the present, writers of the earlier period grappled with ideas of equality, changing notions of race, the complexity of gender roles, and the nature of social class. However, how do educators provide "access" to these concepts while engaging with increasingly diverse and "multicultural” classrooms?

The nature of the classroom can present a number of challenges that impede access, such as the assumptions of the educator, the assumptions of the students, and the time allotted to focus on the materials. Most post-secondary educators are trained unevenly to deal with the complex issues that arise in the classroom, and not enough training occurs to help these educators deal with their own subject-positioning within the classroom-especially if they are faculty of visible color. ${ }^{3}$ My reflection on my own experiences — while admittedly particular to me-will hopefully provide ideas and avenues for individual pedagogical explorations. I consider the challenges of access while teaching at differently multicultural institutions, while trying to mediate between the students and material they might otherwise consider arcane. An additional complication to this access most definitely comes from my own position within the classroom.

To illustrate, I share a recent experience with students at the urban, private university where I currently teach. The Honors literature course at my institution is taught over two semesters in conjunction with history and philosophy, and it attempts to represent as wide a range of literary traditions from around the world as possible. When teaching Lope de Vega's Fuenteovejuna, I asked the faculty member on my campus who had translated the play to give a lecture in my course. He delivered an excellent lecture on the challenges of translation studies, and afterward I asked my students for feedback. One student asked if the faculty member was Spanish, signaling 
clearly that in his perception he associated expertise with ethnicity. When I remarked that I was an English professor with no actual English ancestry, the class paused because they had never questioned my interest in or authority over the material. However, one student did ask why I was not a scholar of Indian literature, a question I have always found difficult to answer because to deny interest in my own heritage seemed to deny the heritage altogether. Yet, limiting my scholarship to my ethnicity also seemed equally inauthentic and unfair. I chose to turn the question back to the students and discuss the need to learn English literature at all-a very murky topic at my university, which is health-science and "practical" education oriented. To my surprise, some students presented class-based arguments about the necessity of "access" to a certain body of knowledge. Their awareness of the role of my course in their education demonstrated a sophistication of thinking that allowed me to push the discussion of our texts in the remainder of the term.

Another interchange with a student caused me to reflect more directly on my own role with respect to modeling access to material. I found myself mentoring an African-American man who wished to pursue graduate studies in Renaissance literature. Initially, I expected to inform him of the current realities of graduate study-both the competitiveness and the difficulty in finding a teaching position. However, I was very surprised by the question he posed about his suitability for pursuing Renaissance studies. He had been told by another African-American faculty member that he would be unwelcome in anything other than African-American studies. This notion hearkened back to my Honor students' expectation that only people of Spanish descent would be interested in or qualified to teach Spanish. This student immediately questioned the advice he had received, and he came to me because I was proof that faculty need not be confined by their ethnicity, race, religion, class, or any other category. I came to realize that as a faculty of visible color, I had an additional responsibility to model access to all students-minority or majority.

The conversation with my Honors class and with this student pushed me to rethink the manner in which I conveyed information in my class. My emphasis on the culture of the time period of whatever text we discussed sometimes derailed the ability to make present day connections. However, I have developed a greater appreciation for making the conversation about any text relate to present issues. The rich complexities of eighteenth-century culture offer almost endless possibilities for making these connections. For example, when I taught Defoe's Roxana, we discussed issues such as the private sphere and gender inequality in a manner that connected clearly with the present. Several of my female students even went so far as to pledge never to marry, given the persistent inequities for women! Access can and should be a combination of having students understand the material in its time and in the present. However, if an educator has only a few classes, rather than an entire semester, in which to foster interest in this field, then how can he or she make the eighteenth century more present, particularly in fast-changing educational environments?

Challenging students to read texts critically with connection to their own lives necessitates a kind of ahistorical analysis in order to make texts relevant to students from all walks of life. In Teaching to Transgress, bell hooks enjoins teachers to move beyond the norm in a way that deconstructs paradigms rather than merely expanding them to include "new" information. She acknowledges that in order to do this, a teacher needs to learn the "cultural codes" of her students 
just as they need to learn the teacher's cultural codes (41). In my experience, this mutual exchange of information in the culture of the classroom is highly mediated by the assumptions students might make about the educator. These assumptions, in all probability, make up a large portion of this mutual exchange of cultural codes that hooks mentions. My challenge in teaching eighteenth-century materials is two-fold-making the material relevant and negotiating the diversity of the classroom (to which my physical presence contributes).

Even the notion of diversity or multiculturalism has taken on various glosses of meaning to accommodate the dynamism of American classrooms. This expansion of meaning is directly the result of the changing demographics of the classroom. Among Caucasian (White) students, the percentage attending college right after high school increased from 50\% in 1980 to $72 \%$ in 2008, a trend shared by other ethnic groups, albeit not with such a high rate of increase. ${ }^{4}$ Students who are predominantly of non-European or "White" descent account for almost $21 \%$ percent of the college population. A larger percentage of older students are attending college after a number of years in the workforce. The gender gap has widened with more women attending college and obtaining degrees. Additionally, college is no longer beyond the reach of those who are not members of the elite or wealthy class. In 2007-2008, approximately $80 \%$ of full-time students received some form of financial aid (Aud, Fox, and KewalRamani vi). Given these trends, I would argue that the diverse or multicultural classroom refers more accurately to the many student trajectories accessible to the general population.

Multicultural education at the primary and secondary school levels has with uneven success prepared this current population of undergraduates for the classroom. The desire to foster cultural awareness at a younger age has taken on a number of forms from broadening the canon, "representing” multiple voices, and/or empowering students to be global citizens. Margaret Alison Gibson effectively summarizes the broader trends in multicultural education and the assumptions that underlie the implementation of multicultural education in the U. S. ${ }^{5}$ She breaks down the education into four forms that begin from the premise that cultural acquisition must be taught in order to create the global citizen. ${ }^{6}$ However, her most valuable point is that multicultural education should be conceptual rather than programmatic in nature. She argues "[g]iven that individuals can and normally do develop competencies in multiple cultures, the question for educators is how best to create learning environments that promote rather than inhibit the acquisition of multicultural competencies” (114). By seeking to develop competencies in addition to literacy, a focus on learning environments offers new ways to think of ourselves as teachers, or rather, as performers of culture. I came to recognize from my two different teaching experiences that my mere presence in the classroom had the potential of advocating for particular sorts of cultural competency.

Teaching is a performance of culture in the classroom, and the subject-positioning of the teacher has a profound impact on information transmission. Faculty of visible color bear an additional burden of negotiating competing cultural spaces while encouraging student engagement with texts from a position that may be challenged in ways not encountered by White faculty. The questions of authenticity and authority are rarely, if ever, directly raised by the student; however, the subtle challenges are ever present. My own experience stems from two very different teaching environments that reflect the complicated nature of classroom interactions. I began my teaching as a graduate student at a predominantly "White" (meaning over $85 \%$ of the 
undergraduates identified as Caucasian) state university in which I usually accounted for one of only two or three visible minorities in the classroom. Subsequently, I obtained a tenure-track position at an urban, private university in which "White" students account for less than thirty percent of the undergraduate population. The contrast between these two teaching environments could not be starker. In the first instance, students spent as much time grappling with my markers of difference as the texts. In the second instance, students looked to me to make the texts culturally relevant because I had managed to reconcile contradictions with my own subject positioning.

Teaching as a female ethnic Other in a rural midwestern university presented a series of challenges that occurred immediately upon entry into the classroom. The very few students of visible color or Other ethnic status tended to keep their distance. I believe that the reason for this distance was an attempt to minimize their already glaring difference. In other words, allying oneself with another person of visible color might make one more of a target. Though unexpected, I could understand their hesitance; I imagined that these students experienced the same sort of culture shock that I had experienced on my arrival at the university. What I did not expect was the difficulty experienced by those students whom I presumed to be part of the "majority." In my first year of teaching, I had a well-intentioned and naive young student state that she had never seen "colored" people before coming to college. This statement allowed me to appreciate fully the degree of shock she encountered in my classroom and helped me to develop a new cultural competency in understanding her upbringing in an ethnically homogeneous community. Taking this student's experience as an exemplar, I began to appreciate the many levels of cultural transformation occurring for her over the course of the semester. Beyond the actual material of the course, she had stereotypes about race and ethnicity physically contradicted in her teacher. Moreover, my lack of accent disallowed any placement in the category of "foreign," although I did have several students provide that kind of challenge by reassuring me that I did not have an "accent.” My authority over material associated with White culturenamely English literature_created new paradigms of understanding that culture and text were not to be placed in rigid categories.

The less open-minded student did not respond with the same willingness to learn from the "outsider within."7 My ethnicity, gender, even the subject matter that I taught necessitated too many paradigm shifts. If students recognized my ethnicity-and many did not-they questioned my placement in an English department. In their experience, South Asians were typically found in engineering, the sciences, or computer science departments and spoke with thick accents. To challenge this stereotype openly, I began to wear traditional clothing once every few weeks. Though it felt very awkward to teach in clothing that I associated with another aspect of my own identity, I believe dressing in such a manner provided an additional context to the literature. I am sure that lecturing about the British class system while dressed in a salwar kameez developed cultural competencies that modeled for students the ability to perform multiple cultures simultaneously. I also began to understand that my students, whom I had read uniformly as White, also performed multiple cultures. The students who came from urban environments felt distanced from the students of rural backgrounds. The strong culture of fraternity and sorority life on campus created additional divisions of Greek and non-Greek. Moreover, the variety of fields of study created further divisions among a population that I had mistakenly read as homogeneous. Once I recognized these divisions and forms of resistance from students, my 
teaching changed. In my final year at this university, I taught Aphra Behn's Oroonoko, not exclusively as a text about slavery, but as a text about the complexity of social divisions.

As is the case with many educators, my course was not exclusively devoted to the eighteenth century; rather, it had the broad and general title of "Women Writers." I had no real parameters for the course, other than gender, so I sought to represent a wide range of writers as well as cultures. We began in the $17^{\text {th }}$ century with Behn and ended in the $20^{\text {th }}$ century with Maxine Hong Kingston. My class had sixty students, mostly "White" women from rural parts of the state. I did have a few male students and a few minority students. In spite of the seeming majority, I did not make the mistake of assuming homogeneity among these students. Our first text was Behn's Oroonoko, which I had them read after only a brief introduction to Behn's biography. Students were completely unfamiliar with the story and many came to class either resistant or fearful. The resistant students expected a lecture on the horrors of African slavery and a denunciation of European perpetrators; the fearful students expected angry outbursts from the few Black students in the class. Of course, neither of these things happened. Having discussion mediated by a Brown woman with no ostensible ties to either community actually freed me to discuss the text in a more subtle fashion.

One of the most noteworthy aspects of the text is Behn's description of Oroonoko as having more European than African features. I asked the students to compare her description of the prince to all the other characters in the story. No other male character received so favorable a description. Then I asked the students to consider how the texts represented inequality. While the students went immediately to the practice of slavery, I asked them to consider Oroonoko's treatment in his native land, claiming that he was too popular for his own good. I focused on the grand love story with Imoinda and questioned his treatment of her. I also challenged them to see the divisions within the white community represented in Surinam. I did have some fear that the discussion would be perceived as glib or shallow. By highlighting Oroonoko's ill-treatment in his homeland, I ran the risk of seeming to endorse slavery. I also feared that students might feel that I was diminishing the importance of a historical fact by exploring other facets of the narrative.

However, my fears proved unfounded when one brave soul ventured to comment that the text proved that "not all white people were bad." Another student made a conceptual leap and speculated on how difficult it must have been for an Englishwoman to publish such an antislavery piece. A third student responded to this comment by questioning whether the narrative was antislavery at all since only Oroonoko seemed to be special. All of the students came to feel comfortable speaking of race, class, and gender as interchangeable yet equally important facets of the story. The discussion of this "older" text subsequently carried through the semester into the more contemporary works. Imagine my surprise as students drew parallels between Imoinda and Maxine Hong Kingston’s “Warrior Woman.” In encouraging this class to see the social divisions exemplified in one text, I found them willing to acknowledge a commonality between multiple texts and cultures.

Having been trained in this deceptively homogeneous environment in which I performed my identity in order to challenge multiple stereotypes, I experienced absolute culture shock in my full-time teaching position. I teach at a large, urban, private university that also demonstrates 
diversity in several ways. The student population is overwhelmingly female (71\%) and the ethnic makeup is 38\% Black, 27\% White, 22\% Asian, and 13\% Hispanic ("University Facts"). What I discovered soon after joining the university was that categories of Black or White failed to encompass the vast differences in the student body. A significant portion of the Black students identify as Caribbean, differentiating themselves from African Americans and further subdividing into Haitian, Dominican, Jamaican, Bajan, etc. Guyanese students have an even more complex set of associations. White students also do not fall into simple categories as many students came from immigrant families and maintain strong ethnic identities (complete with accents). What I found astonishing is that my Other-ness now worked in a completely different way. Students of color responded very positively to a faculty member who looked more like them, even if I did not belong to exactly the same community. One student referred to me as "Black," demonstrating a fascinating political awareness of place and ethnicity. White students adjusting to the mixed environment of the university viewed me as yet another aspect of the diversity of the city. They also looked to me for help in negotiating the complexities of being in the minority. However, the acceptance from the students was offset by a new set of challenges to my teaching. Students felt comfortable openly questioning my desire to teach what they perceived to be an obscure set of texts from a century and culture far removed from my own.

Teaching an entire course on the eighteenth century is rare at my university; however, I find ways to expose students to selected texts in any course I teach. My undergraduate "survey" courses either begin or end in the eighteenth century, but the nature of survey precludes the opportunity to present much context. Oroonoko taught very differently in this context as students readily made connections to affirmative action, race privilege, and gender disparities. In direct contrast to my previous experience, in this class the text did incite vehement arguments between White and Black students on the topic of race. White students from new immigrant communities felt disconnected from this history and resentful of its imposition on their perceived status within society. Black students from different communities-African-American, Anglophone-Caribbean, Francophone-Caribbean, and Hispano-Caribbean—also argued about the nature of enslavement. No group felt intimidated to express its opinions, and I was as much referee as mediator. Moreover, several incorrect and polemical arguments began to surface about the African slave trade and the North American experience as universal. I spent more time correcting this misinformation than discussing the text. The nature of the survey course necessitated that I move on from the text. Though students immediately made important connections to their present, I did not feel that I had helped them fully to understand these connections and correct any misperceptions about either Behn's time period or our own.

Because I did not want to shortchange this text, I began to teach texts that were less culturally loaded for this population. While the conditions of the eighteenth-century are important to understand the complexities of a given text, writers like Eliza Haywood in particular provide stories that can proliferate into multiple forms of cultural production. Her characters can embody a kind of fluid ethnicity, more broadly defined as European rather than English. She also specializes in writing about character situations in such a way that students can access the writing with minimal background in the period. This is crucial in teaching a survey because I may only be able to spend three classes on a text. I have taught Love in Excess and Fantomina with enormous success. Haywood's novels speak to the excessive emotions and teen angst that are accessible to every kind of student. One student compared Fantomina's obsession with 
Beauplaisir to Bella and Edward from the Twilight series. Another student commented that the story resembled a telenovella. My concern that the students would not find a point of access to a story about an eighteenth-century spoiled noblewoman proved unfounded.

In my most recent experience teaching Fantomina, I discovered new "cultural codes" that could be accessed in understanding this story. The students discussed the text with respect to the theme of identity. Many students felt that Fantomina had no sense of personal identity until she discovered her obsession with Beauplaisir. Other students viewed her as immature and naive with no respect for social codes. A lively discussion ensued about the age-old double standard regarding male and female sexuality that still operates in today's culture. A few students connected the various guises adopted by Fantomina as examples of the upper class exploitation of lower class women. The two most surprising interpretations of the text occurred after class and during a subsequent discussion. One student, a young woman of Guyanese descent, followed me back to my office after class. She apologized for her lack of participation in class and explained that she could not participate because the text seemed to mirror her life. She proceeded to make connections to her own behavior in high school and her rather self-destructive attraction to a "bad boy." She completed her narration by expressing her surprise she could find such a personal connection with such an "old” story.

A second student initiated an equally complex set of associations by characterizing Fantomina as “insane." This student, a young African-American man, roused the class into a discussion of Fantomina's mental state in her obsession with sex and love. Another student, a Nigerian immigrant, argued passionately for the depth of her affections, while a third student (a Puerto Rican woman) responded with derision that the elaborate nature of her disguises made her seem more interested in being pursued. I mark the ethnicity of the students to illustrate both the multicultural nature of the classroom and the manner in which the text drew them into present day concerns. In my class of twenty-five students, only one woman identified as Caucasian. The class was a mixture of multiple ethnicities, immigrants and those raised in the States, men and women. No one appeared to feel that the narrative was dated.

When I suggested that perhaps Fantomina in her disguise had adopted more of a masculine role in the story, the class began to debate the behavior of Beauplaisir. How could he possibly be duped by each disguise? Would he not recognize her body after repeated encounters? The students moved naturally and unabashedly into a discussion of sexual mores. Without sharing personal experiences, this group clearly demonstrated an understanding of both the expression of sexual desire and the anonymity of its expression. Some students connected Beauplaisir's behavior to the self-serving "player" whose primary impetus was conquest not commitment. Others questioned Haywood's authenticity in representing the experience, reading these disguises as an odd form of authorial innocence in understanding the significance of sexual contact. The entire range of the conversation included frequent references to popular culturesome of which I made. Given the limited time allotted in the class for this text, I did not spend too much time setting up the background for the narrative. Instead, I found that I was able to incorporate the background as students debated the character depictions and motivations. In this way, even students who initially complained about the difficulty of the language began to appreciate the richness of the text. All the students agreed uniformly that the story had a profound relevance to modern American society, even if it was “old.” 
In reflecting upon my experiences at these two vastly different university settings, I return to the concept of access. As educators, we can be sensitive to the changing dynamics of the classroom by reflecting on the manner of access to the material and multiculturalism as a conceptual framework. Eighteenth-century texts that are taught as part of surveys do not afford faculty with adequate time to acquaint students fully with the complexity of the period. However, they do offer topics of pointed relevance to our own time. Learning new cultural codes can encourage students' access to the text by developing their own points of entry into the material. Moreover, this form of access empowers students to comprehend text through the lens of personal experience.

The multicultural classroom also encompasses many iterations that always include the educator herself. To understand the classroom, educators need to remain open to their own assumptions about students as well as student assumptions about the educator. In teaching and claiming authority over a host of categories in the literature and culture of Great Britain, I allow students to recognize that one form of cultural literacy need not supplant other existing forms. Instead, in true eighteenth-century fashion, students are capable of developing multiple competencies. These insights may be difficult to measure in higher education's push for outcomes assessment and the quantification of learning. However, our field offers students of any background the opportunity to understand how the cultures of the past remain in the present. 


\section{Notes}

1. Hirsch's extremely conservative view of literacy overwhelmingly privileges Western modes of knowledge, a fact that many critics were quick to point out. However, there is a certain underlying and tacit agreement that specific bodies of knowledge are necessary to enter the ranks of the cultural elite. While we may quibble over the shape and consistency of that body, the need for the body itself is not questioned.

2. Both MLA and the American Society for Eighteenth-Century Studies (ASECS) have actively promoted pedagogical innovation. For example, the recent MLA publication, Teaching British Women Playwrights of the Restoration and Eighteenth Century, edited by Bonnie Nelson and Catherine Burroughs (2010), features several essays on how to integrate new plays into the classroom and some of the challenges involved in doing so. Also, the ASECS innovative course design contest and poster displays at the annual conference are excellent resources for scholars seeking new ways to present material from the period.

3. I am indebted to Dr. Rosamond King for giving me the vocabulary to note this distinction. In this essay, I consider student reactions to appearance as a marker of race or ethnicity; thus, I am qualifying the expression "woman of color" because color is marked visibly on my body. This qualifier is not intended to detract from any individual's identification with an ethnic identity that is not expressed phenotypically; however, I do contend that differences exist.

4. See Status and Trends in the Education of Racial and Ethnic Groups by Susan Aud, Mary Ann Fox, and Angelina KewalRamani. This publication is part of a series published by the National Center for Education Statistics and the Institute for Education Sciences. This report examines data from 2008 and 2009 against data gathered in 1980 to illustrate that college enrollment has increased overall in the general population. While gaps still exist in the rate of enrollment of minorities as compared to the majority, the classroom is becoming more diverse.

5. Though Gibson's article is dated, the strategies outlined have become standard to the field. In Christine Bennett's “Genres of Research in Multicultural Education,” she clusters strategies into much the same categories as outlined by Gibson’s article.

6. One form seeks to even the playing field and is directed exclusively towards students from ethnic backgrounds who are disadvantaged by testing that speaks to the mainstream (95-98). A second approach speaks to all students in teaching tolerance and the appreciation of broader cultural differences (98-102). The third and fourth approaches address the cultural diversity of American society by advocating a pluralist model of multiculturalism (102-107) or a bicultural model through second language acquisition (107-111).

7. I am indebted to Black feminist educators like Patricia Hill Collins, Audre Lorde, and bell hooks for discussing extensively the intersection of race and the classroom. Though 
my own "race" is not as inflected by a history of American oppression, I find that understanding their experiences helps me make sense of my own. See in particular, Patricia Hill Collins, Black Feminist Thought; Audre Lorde, Sister Outsider; and bell hooks, Teaching to Transgress. 
Works Cited

Aud, Susan, Mary Ann Fox, and Angelina KewalRamani. Status and Trends in the Education of Racial and Ethnic Groups. U.S. Department of Education, July 2010. Web. 23 Feb. 2012 http://nces.ed.gov/pubs2010/2010015.pdf.

Bennett, Christine. "Genres of Research in Multicultural Education.” Review of Educational Research 71.2 (2001): 171-217. Print. http://dx.doi.org/10.3102/00346543071002171

Collins, Patricia Hill. Black Feminist Thought: Knowledge, Consciousness, and the Politics of Empowerment. New York: Routledge, 2000. Print.

Gibson, Margaret Alison. "Approaches to Multicultural Education in the United States: Some Concepts and Assumptions.” Anthropology and Education Quarterly 15.1 (1984): 94120. Print. http://dx.doi.org/10.1525/aeq.1984.15.1.05x1476t

Hirsch, Jr., E.D. Cultural Literacy: What Every American Needs to Know. New York: Vintage, 1988. Print.

hooks, bell. Teaching to Transgress: Education as the Practice of Freedom. New York: Routledge, 1994. Print.

Lorde, Audre. Sister Outsider: Essays and Speeches by Audre Lorde. Berkeley: Crossing Press, 2007. Print.

“University Facts in Brief.” Long Island University. N.p. 2012. Web. 23 Feb. 2012. 